$\mathrm{DE}$

M E D I C I N A

T R O P I C A L

$\mathrm{DE}$

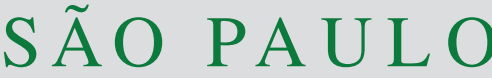

JOURNAL OF THE SÃO PAULO INSTITUTE OF TROPICAL MEDICINE

1 Universidade Estadual Paulista (UNESP), Faculdade de Odontologia de Araçatuba, Programa de Pós-Graduação em Odontologia Preventiva e Social, Araçatuba, São Paulo, Brazil

${ }^{2}$ Centro Universitário Católico Salesiano Auxilium, Curso de Medicina, Araçatuba, São Paulo, Brazil

Correspondence to: Clea Adas Saliba Garbin

Universidade Estadual Paulista (UNESP), Faculdade de Odontologia de Araçatuba, Programa de Pós-Graduação em Odontologia Preventiva e Social, Rua José Bonifácio, 1193, Bairro Vila Mendonça, CEP 16015-050, Araçatuba, SP, Brazil Tel: +55 18 3636-3250, +55 18991648440

E-mail: clea.saliba-garbin@ unesp.br, brunowakayama@gmail.com

Received: 29 November 2019

Accepted: 3 February 2020

\section{A cross-sectional study on dental surgeons' immune status against hepatitis B virus in the Public Health System}

\author{
Clea Adas Saliba Garbin ${ }^{(1)}$, Bruno Wakayama ${ }^{(1)}$, Tânia Adas Saliba ${ }^{(1)}$, \\ Orlando Adas Saliba Junior ${ }^{\circledR 2}$, Artênio José Ísper Garbin ${ }^{\left({ }^{1} 1\right.}$
}

\section{ABSTRACT}

Hepatitis B is a severe public health problem. The main world health centers have discussed it due to its pandemic proportion, high pathogenicity and infectivity. This study aimed to determine the immunization profile of dental surgeons - against hepatitis B virus (HBV) in the Public Health System (PHS) through the detection of anti-HBsAg antibodies by immunochromatography and associations with dental surgeons' social and educational profile, factors related to professional knowledge and practices. This is a cross-sectional study on the prevalence of vaccination and immune status to HBV in dentists of Sao Paulo State PHS. Data collection occurred in three stages: questionnaire application, analysis of adhesion to the vaccination protocol and anti-HBsAg tests. Statistical analysis used the Bivariate Analysis and the Binary Logistic Regression. From the total of 219 interviewees, $74.9 \%$ reported having received three doses of the vaccine, but $35.6 \%$ were not immune to HBV. The dependent variable was associated with years in the public service (years) (OR [Odds Ratio]=1.04; 95\% CI 1.00-1.08); knowledge on the subject ( $\mathrm{OR}=6.93$; 95\% CI 1.39-34.40); incorrect answer concerning the etiological agent of the disease ( $\mathrm{OR}=2.60 ; 95 \% \mathrm{CI} 1.30-5.22)$; ignorance on the number of vaccine doses that have been administered $(\mathrm{OR}=3.43$; 95\% CI 1.14-10.30); and less than three doses of the vaccine in the immunization schedule $(\mathrm{OR}=8.76 ; 95 \% \mathrm{CI} 3.50-21.91)$. A considerable portion of professionals non-immune to the $\mathrm{HBV}$ were found. We concluded that knowledge, years of practice and completion of the vaccination schedule (three doses) affected dental surgeons' immune status to HBV.

KEYWORDS: Hepatitis B. HBV. Anti-HBsAg. Australian antigen. Vaccination. Immunization. Dentistry.

\section{INTRODUCTION}

Hepatitis B consists of a severe infection in the liver. It is a pandemic disease with significant epidemiological indices. Estimates have suggested that about 2 billion people are infected with hepatitis B virus (HBV), and approximately 325 million live with chronic liver disease without access to diagnostic tests and treatments ${ }^{1,2}$.

Among viral hepatitis, the $\mathrm{B}$ and $\mathrm{C}$ types account for $96 \%$ of deaths and morbidity rates due to cirrhosis and liver cancer in the world ${ }^{2}$. For that reason, the World Health Organization (WHO) has published guidelines and recommendations to warn health services and professionals about the risks of infection, the importance of prevention and the need of implementing public health policies related to this disease $^{1}$. Likewise, a manual published in 2017 on tests to diagnose hepatitis B and $\mathrm{C}$ aimed at encouraging, expanding and strengthening health coordinated actions to make these laboratory tests available to the main vulnerable groups ${ }^{3}$. 
The great discussion about hepatitis B in the main world health centers is related to the high HBV infectivity and antiviral resistance which is up to 100 times higher than that of the human immunodeficiency virus (HIV) ${ }^{4}$ and 10 times higher than that of the hepatitis $\mathrm{C}$ virus $(\mathrm{HCV})^{5,6}$. This characteristic is related to the social conjecture, particularly in developing countries, since this disease is mainly silent and asymptomatic. Furthermore, it can evolve through different paths depending on the age, lifestyle and the patient's general health condition, aside from HBV genotypes and subgenotypes and mode of the pathogen's acquisition ${ }^{7,8}$.

The vulnerable groups to this disease include health care professionals, who have a higher prevalence of $\mathrm{HBV}$ infections than the general population, regardless of the endemic condition in the region where they live $\mathrm{e}^{9,10}$. Therefore, approaching this subject in relation to dental professionals is essential, since they perform unsanitary activities in continuous and direct contact with the main modes of HBV transmission: blood and saliva ${ }^{11,12}$. Besides, associated factors make dental surgeons more susceptible to this disease: high rates of laboratory accidents with contaminated sharp equipment, poor biosafety practices, negligent self-care, high virus pathogenicity and lack of immunization against $\mathrm{HBV}^{13,14}$.

The vaccine against $\mathrm{HBV}$ was developed in the 1970s. Since 1986, it has been widely distributed and has demonstrated to be highly reliable, accurate and safe, so that it is considered the main preventive method against hepatitis B. For this reason, this preventive measure (vaccination) is not only a self-care practice of dental surgeons, but also the most efficient measure to protect patients' health, reducing the incidence of the disease ${ }^{15}$.

Even though the vaccine is highly immunogenic, around $10 \%$ of individuals who have completed their immunization schedule with three doses $(0,30$ and 180 days) do not develop protective immunity, i.e., their antibody titers against HBV surface's antigen (anti-HBs) are lower than $10 \mathrm{mIU} / \mathrm{mL}$. The main procedure to ascertain immunization is by performing a post-vaccination anti-HBs seroconversion test ( 6 to 8 weeks after the last dose) using enzyme immune assays and immunochromatography. The seroconversion status is an essential information for health professionals, as a booster dose may be necessary to stimulate the production of higher antibody levels ${ }^{16,17}$.

Thus, considering that the Brazilian public health is one of the main sectors concentrating the labor force of dental surgeons in the country and that few researches have determined the vaccine protection status and prevalence in this risk group through a reliable, recommended, laboratorybased methodology, accessible to the population, this study aimed to determine in the dental surgeons working in the
Public Health System (PHS), their immune profile against HBV by means of anti-HBsAg enzyme immunoassays and immunochromatography, and its association with the social and educational profile of dental surgeons, as well as with factors related to professional knowledge and practices.

\section{MATERIALS AND METHODS}

\section{Study design}

This is a cross-sectional epidemiological study. Its population comprises all of the dental surgeons in the PHS, in all the 40 municipalities (a total of 774,441 inhabitants) in the Northwest region of Sao Paulo State covered by the Regional Health Department II (DRS II).

Sao Paulo State is located in the Southeast region of Brazil and has the highest number of dental surgeons in the country. Administratively, Sao Paulo is divided into 17 Regional Health Departments ${ }^{18}$ to meet the Brazilian Unified Health System's (SUS) guidelines and to comply with the institutional reforms agreed by the federated entities (the Union, States and municipalities) in the 2006 Covenant for Health Care (Pacto pela Saude) (Ordinance $\left.\mathrm{N}^{\circ} 3999 / 2006\right)^{19}$.

According to the information provided by the DRS II at the time of data collection, there were 276 active dental surgeons in the Public Health System. All the professionals who accepted participating in the study signed the Informed Consent. The exclusion criteria comprised municipal managers who did not authorize to carry out the study in their cities and dental surgeons who were laid off or were on work leave or maternal leave, retired, retirees of those who were absent after two visits during the data collection period.

\section{Data collection}

We divided the data collection into three stages as follows.

\section{$1^{\text {st }}$ Stage}

The first stage consisted of the application of a self-administered, semi-structured questionnaire. This instrument has been developed for this research. In order to design it, we conducted a wide bibliographic survey to include valid, sensitive and inferential variables. We divided the instrument into three dimensions: the first one has covered issues related to social, educational and demographic characteristics of the interviewees; the second dimension has investigated the representativeness of the professionals' knowledge and mastery regarding the hepatotropic virus type $\mathrm{B}$, the transmissibility of viral 
pathogens and the immunogenicity of the vaccine against $\mathrm{HBV}$; and the third dimension determined the participants' valuation of their self-care practices.

We carried out a pilot study to investigate the instrument's applicability and operability to meet the study goal. The application of the instrument occurred in the participants' workplace, without disturbing or interfering with the clinic organization and the scheduled appointments.

\section{$2^{\text {nd }}$ Stage}

After the first stage, participants were individually forwarded to a private room provided by each health institution. At this moment, we requested the participants' immunization record and verified the completeness of the immunization protocol against HBV (three doses of the vaccine). In addition, we questioned the participants about the previous anti-HBs seroconversion test and its result.

\section{$3^{\text {rd }}$ Stage}

The last study stage verified the participants' immunization status through a rapid anti-HBsAg ${ }^{\circledR}$ immunochromatographic assay (Wama Diagnostica, Sao Carlos, SP, Brazil). The data collection procedures followed all biosafety rules and recommendations to protect the physical integrity of the participants and guarantee the tests reliability and sensitivity.

The rapid test is based on the immunochromatographic technology; it uses the sandwich principle to detect antiHBsAg antibodies in human serum, plasma, or whole blood. Firstly, blood was collected through a fingerstick procedure with a sterile, disposable lancet. Then, blood from the fingertip was collected with a capillary tube. An approximate blood volume of $100 \mu \mathrm{L}$ was immediately placed in the sample well indicated by the device. The result was read 15-20 min after the beginning of the assay.

The device employed is based on an immunochromatographic method. A positive result (the individual is considered immunized), occurs when the antibodies against the HBV surface antigen (anti-HBs) present in the sample bind to the HBsAg-colloidal gold conjugate, forming antigen-antibody complexes. This ensemble moves to the test area $(\mathrm{T})$, where it binds to HBsAg antigens and shows a reddish pink band. Next, the remaining ensemble flows to the control area (C) and binds to anti-HBsAg antibodies in the control area, showing a second reddish pink band in this region, therefore determining the immunized status.

Negative results indicate that the individual was not immunized at all or that there is an insufficient level of antibodies, determining the non-immune status of individuals $(<10 \mathrm{mIU} / \mathrm{mL})$. This confirmation occurs when there is only one reddish pink band in the control area (C), while the test area does not show any reaction (pink band).

\section{Data analysis}

We performed data tabulation and statistical analysis using the Statistical Package for the Social Sciences (SPSS for Windows, version 22.0, IBM, Armonk, New York, USA), and carried out the bivariate analysis using the Pearson's chi-square test, Fisher's exact test or the maximum likelihood ratio test, with a p-value $<0.050$ to verify associations between dependent and independent variables. Concerning the quantitative variables analyses (age, years after graduation, years in the public service), we initially applied the Kolmogorov-Smirnov test for normality $(\mathrm{p} \leq 0.05)$. However, as this test did not meet our purpose, we used the Mann-Whitney non-parametric test, considering a significance level of $5 \%(\mathrm{p} \leq 0.05)$.

Next, we conducted a binomial logistic regression analysis with gross and adjusted estimates of odds ratios (OR) in order to control confounding variables and to identify factors modifying the mentioned event. This model included all the associations found between the dependent variable and the corresponding independent variables, considering a p-value $<0.001$. The confidence interval was adjusted to $95 \%$ and results were displayed as ORs.

\section{Ethical and legal aspects}

This research was approved by the Ethics and Research Committee (Protocol N ${ }^{\circ}$ CAAE 54227416.0.0000.5420) and it complied with all ethical principles for research with human beings according to Resolution $N^{\circ} 466 / 2012$ of the Brazilian National Health Council.

\section{RESULTS}

From a total population of 276 dental surgeons, four were on work or maternal leave, 24 did not want to participate in the study and 16 were not present after two interview attempts. In addition, 13 professionals did not participate in the study because three managers did not authorize the study in their cities. Therefore, the sample comprised 219 (79.4\%) dental surgeons from 37 cities. We identified that $95.9 \%$ of participants reported to be immunized against $\mathrm{HBV}$ and $74.9 \%$ received at least three doses of the vaccine. However, the anti-HBsAg seroconversion test indicated that $35.6 \%$ of dental surgeons were not immunized against HBV.

Table 1 shows the dental surgeons' social and educational profile. Most participants were female (65.8\%), 
Table 1 - Bivariate analysis of social and educational factors with respect to the dependent variable (immunization to hepatitis B). Sao Paulo, Brazil, 2019.

\begin{tabular}{|c|c|c|c|c|c|c|c|}
\hline \multirow{3}{*}{ Social and educational factors } & \multicolumn{4}{|c|}{$\begin{array}{c}\text { What is the result of the immunization } \\
\text { test? }\end{array}$} & \multirow{2}{*}{\multicolumn{2}{|c|}{ Total }} & \multirow{3}{*}{$p$-value } \\
\hline & \multicolumn{2}{|c|}{ Non immunized } & \multicolumn{2}{|c|}{ Immunized } & & & \\
\hline & $\mathrm{n}$ & $\%$ & $\mathrm{n}$ & $\%$ & $\mathrm{n}$ & $\%$ & \\
\hline Sex & & & & & & & 0.062 \\
\hline Male & 33 & 42.3 & 42 & 29.8 & 75 & 34.2 & \\
\hline Female & 45 & 57.7 & 99 & 70.2 & 144 & 65.8 & \\
\hline Marital status & & & & & & & 0.298 \\
\hline Not married & 28 & 35.9 & 41 & 29.1 & 69 & 31.5 & \\
\hline Married/Common-law marriage & 50 & 64.1 & 100 & 70.9 & 150 & 68.5 & \\
\hline Age group (years) & & & & & & & $0.493^{\star \star}$ \\
\hline 20 to 29 & 9 & 11.5 & 16 & 11.3 & 25 & 11.4 & \\
\hline 30 to 39 & 12 & 15.4 & 34 & 24.1 & 46 & 21.0 & \\
\hline 40 to 49 & 31 & 39.7 & 48 & 34.0 & 79 & 36.1 & \\
\hline 50 to 59 & 20 & 25.6 & 37 & 26.2 & 57 & 26.0 & \\
\hline 60 or older & 6 & 7.7 & 6 & 4.3 & 12 & 5.5 & \\
\hline Ethnicity & & & & & & & $0.262^{* \star}$ \\
\hline White & 60 & 76.9 & 116 & 82.9 & 176 & 80.4 & \\
\hline Mixed (black and white) & 6 & 7.7 & 4 & 2.9 & 10 & 5.0 & \\
\hline Asian & 12 & 15.4 & 20 & 14.3 & 32 & 14.6 & \\
\hline Years after graduation & & & & & & & 0.189 \\
\hline$<5$ & 7 & 9.0 & 12 & 8.5 & 19 & 8.7 & \\
\hline 5 to 10 & 6 & 7.7 & 17 & 12.1 & 23 & 10.5 & \\
\hline 11 to 20 & 13 & 16.7 & 38 & 27.0 & 51 & 23.3 & \\
\hline 21 to 30 & 39 & 50.0 & 49 & 34.8 & 88 & 40.2 & \\
\hline$>30$ & 13 & 16.7 & 25 & 17.7 & 38 & 17.4 & \\
\hline Years in the public healthcare service & & & & & & & $0.172^{\star \star}$ \\
\hline$<5$ & 7 & 9.0 & 27 & 19.1 & 34 & 15.5 & \\
\hline 5 to 10 & 11 & 14.1 & 26 & 18.4 & 37 & 16.9 & \\
\hline 11 to 20 & 27 & 34.6 & 42 & 29.8 & 69 & 31.5 & \\
\hline 21 to 30 & 32 & 41.0 & 43 & 30.5 & 75 & 34.2 & \\
\hline$>30$ & 1 & 1.3 & 3 & 2.1 & 4 & 1.8 & \\
\hline Workload & & & & & & & 0.106 \\
\hline Up to $20 \mathrm{HPW}^{* * *}$ & 54 & 69.2 & 82 & 58.2 & 136 & 62.1 & \\
\hline$>20 \mathrm{HPW}$ & 24 & 30.8 & 59 & 41.8 & 83 & 37.9 & \\
\hline Schooling & & & & & & & $0.575^{\star \star}$ \\
\hline Undergraduate Course & 40 & 51.3 & 60 & 42.6 & 100 & 45.7 & \\
\hline Specialist Degree & 35 & 44.9 & 72 & 51.1 & 107 & 48.9 & \\
\hline Master's Degree & 2 & 2.6 & 7 & 5.0 & 9 & 4.1 & \\
\hline $\mathrm{PhD}$ & 1 & 1.3 & 2 & 1.4 & 3 & 1.4 & \\
\hline Smoker & & & & & & & $1.000^{*}$ \\
\hline No & 73 & 93.6 & 133 & 94.3 & 206 & 94.1 & \\
\hline Yes & 5 & 6.4 & 8 & 5.7 & 13 & 5.9 & \\
\hline Use of alcoholic beverages & & & & & & & 0.014 \\
\hline No & 28 & 35.9 & 75 & 53.2 & 103 & 47.0 & \\
\hline Yes & 50 & 64.1 & 66 & 46.8 & 116 & 53.0 & \\
\hline Sexual orientation & & & & & & & $0.289^{*}$ \\
\hline Heterosexual & 76 & 97.4 & 140 & 99.3 & 216 & 98.6 & \\
\hline Homosexual & 2 & 2.6 & 1 & 0.7 & 3 & 1.4 & \\
\hline Relative who had or has hepatitis B & & & & & & & $0.776^{*}$ \\
\hline No & 74 & 94.9 & 132 & 93.6 & 206 & 94.1 & \\
\hline Yes & 4 & 5.1 & 9 & 6.4 & 13 & 5.9 & \\
\hline Total & 78 & 100.0 & 141 & 100.0 & & & - \\
\hline
\end{tabular}

*Fisher's exact test; **Maximum likelihood ratio; ${ }^{* \star *} \mathrm{HPW}-$ hours per week. 
married (68.5\%), have graduated from 21 to 30 years ago (34.2\%), have worked for 1 to 20 years in the public service and held a specialist degree (48.9\%). We found a statistically significant association between the use of alcoholic beverages and the participants' immunization (Table 1).

Table 2 shows that most professionals reported having received guidance on hepatitis B (94.5\%), and this information was provided during their undergraduate program $(48.3 \%)$. However, the average years after graduation is 20.93 ( $\mathrm{SD} \pm 10.08$ ), and $92.7 \%$ have not attended any course in the past two years. Half $(50.2 \%)$ of interviewees were wrong in answering what is the etiological agent of hepatitis B, $72.1 \%$ confused or gave an incomplete answer on the modes of transmission of the disease, and only $19.2 \%$ correctly answered the preventive measures against the disease in the dental clinic. The dependent variable showed statistically significant associations with "He/She received guidance on hepatitis B" $(\mathrm{p}=0.009)$ and "He/She knows the etiologic agent" $(\mathrm{p}=0.000)$ (Table 2).

Table 3 shows the dental surgeons' self-care practices with $95.9 \%$ having stated that they had been vaccinated against HBV; however, $23.8 \%$ of participants did not know how many doses they had received or they had received less than three doses. This situation occurred because some participants did not bring their immunization card to the interview, as previously requested. Only 80 (36.5\%) dental surgeons had performed the anti-HBs assay previously, and $32.8 \%$ of them had a negative immunization result. Another result had great representativeness in almost half of the participants (48.4\%) who reported having already

Table 2 - Bivariate analysis of knowledge factors and the dependent variable (immunization to hepatitis B), Sao Paulo, Brazil, 2019.

\begin{tabular}{|c|c|c|c|c|c|c|c|}
\hline \multirow{3}{*}{ Knowledge factors } & \multicolumn{4}{|c|}{$\begin{array}{l}\text { What is the result of the } \\
\text { immunization test? }\end{array}$} & \multirow{2}{*}{\multicolumn{2}{|c|}{ Total }} & \multirow{3}{*}{$\mathrm{p}$-value } \\
\hline & \multicolumn{2}{|c|}{ Non immunized } & \multicolumn{2}{|c|}{ Immunized } & & & \\
\hline & $\mathrm{n}$ & $\%$ & $\mathrm{n}$ & $\%$ & $\mathrm{n}$ & $\%$ & \\
\hline Received guidance on hepatitis $B$ & & & & & & & $0.009^{*}$ \\
\hline No & 9 & 11.5 & 3 & 2.1 & 12 & 5.5 & \\
\hline Yes & 69 & 88.5 & 138 & 97.9 & 207 & 94.5 & \\
\hline If yes, where? & & & & & & & 0.003 \\
\hline Undergraduation & 30 & 43.5 & 70 & 51.5 & 100 & 48.3 & \\
\hline Graduation & 3 & 4.3 & 25 & 18.4 & 28 & 13.5 & \\
\hline Public Service & 12 & 17.4 & 18 & 13.2 & 30 & 14.5 & \\
\hline Media & 24 & 34.8 & 23 & 16.9 & 47 & 22.7 & \\
\hline Attended any course in the past two years & & & & & & & 0.480 \\
\hline No & 71 & 91.0 & 132 & 93.6 & 203 & 92.7 & \\
\hline Yes & 7 & 9.0 & 9 & 6.4 & 16 & 7.3 & \\
\hline Knowledge the etiologic agent & & & & & & & 0.000 \\
\hline Incorrect answer & 52 & 66.7 & 58 & 41.4 & 110 & 50.2 & \\
\hline Correct answer & 26 & 33.3 & 82 & 58.6 & 108 & 49.3 & \\
\hline What is the risk of contracting hepatitis $B$ ? & & & & & & & $0.894^{\star \star}$ \\
\hline High & 59 & 78.7 & 107 & 75.9 & 166 & 75.8 & \\
\hline Medium & 13 & 17.3 & 28 & 19.9 & 41 & 18.7 & \\
\hline Low & 3 & 4.0 & 6 & 4.3 & 9 & 4.1 & \\
\hline Modes of transmission of hepatitis B & & & & & & & 0.855 \\
\hline Incorrect answer & 9 & 11.5 & 13 & 9.2 & 22 & 10.0 & \\
\hline Correct answer & 21 & 26.9 & 40 & 28.4 & 61 & 27.9 & \\
\hline Incomplete answer & 48 & 61.5 & 88 & 62.4 & 136 & 62.1 & \\
\hline $\begin{array}{l}\text { The main preventive measure against hepatitis } B \text { in the } \\
\text { dental clinic }\end{array}$ & & & & & & & 0.885 \\
\hline Incorrect answer & 10 & 12.8 & 20 & 14.2 & 30 & 13.7 & \\
\hline Correct answer & 14 & 17.9 & 28 & 19.9 & 42 & 19.2 & \\
\hline Incomplete answer & 54 & 69.2 & 93 & 66.0 & 147 & 67.1 & \\
\hline Does the vaccination against hepatitis $B$ last a lifetime? & & & & & & & 0.683 \\
\hline No & 39 & 56.5 & 69 & 53.5 & 108 & 49.3 & \\
\hline Yes & 30 & 43.5 & 60 & 46.5 & 90 & 41.1 & \\
\hline Total & 78 & 100.0 & 141 & 100.0 & & & - \\
\hline
\end{tabular}

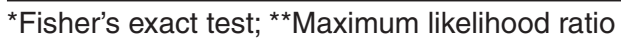


had a history of accident with sharp instruments, with recurrence in $62.2 \%$ of the cases, mainly when recapping needles $(66 \%)$. Even though $76 \%$ of participants were aware of the protocol for accidental puncture wounds, less than half $(53 \%)$ sought medical care or performed any exams (Table 3).

Concerning the bivariate analyses, the immunization profiles of participants had statistically significant associations with the variable "How many doses of the vaccine against hepatitis B have you received?" $(p=0.000)$ and "Do you wash your hands after each clinical appointment?" ( $p=0.036)$. Furthermore, the Mann-Whitney test found associations with the number of years in the public service $(\mathrm{p}=0.038)$.

The multivariate analysis (Table 4) carried out through the binomial logistic regression indicated that the number

Table 3 - Bivariate analysis of factors related to professional practices and the dependent variable (immunization to HBV) -Brazil, 2019.

\begin{tabular}{|c|c|c|c|c|c|c|c|}
\hline \multirow{3}{*}{ Factors related to professional practices } & \multicolumn{4}{|c|}{$\begin{array}{c}\text { What is the result of the immunization } \\
\text { test? }\end{array}$} & \multirow{2}{*}{\multicolumn{2}{|c|}{ Total }} & \multirow{3}{*}{ p-value } \\
\hline & \multicolumn{2}{|c|}{ Non immunized } & \multicolumn{2}{|c|}{ Immunized } & & & \\
\hline & $\mathrm{n}$ & $\%$ & $\mathrm{n}$ & $\%$ & $\mathrm{n}$ & $\%$ & \\
\hline Received the vaccine & & & & & & & $0.072^{*}$ \\
\hline No & 6 & 7.7 & 3 & 2.1 & 9 & 4.1 & \\
\hline Yes & 72 & 92.3 & 138 & 97.9 & 210 & 95.9 & \\
\hline $\begin{array}{l}\text { How many doses of the vaccine against hepatitis B did } \\
\text { you receive? }\end{array}$ & & & & & & & 0.000 \\
\hline Do not know/ Do not remember & 14 & 18.2 & 7 & 5.0 & 21 & 9.6 & \\
\hline Less than three doses & 21 & 27.3 & 10 & 7.2 & 31 & 14.2 & \\
\hline Three doses or more & 42 & 54.5 & 122 & 87.8 & 164 & 74.9 & \\
\hline Have you ever performed the anti-HBs test? & & & & & & & 0.375 \\
\hline No & 52 & 66.7 & 83 & 60.6 & 135 & 61.6 & \\
\hline Yes & 26 & 33.3 & 54 & 39.4 & 80 & 36.5 & \\
\hline If yes, what was the result? & & & & & & & 0.053 \\
\hline Negative & 13 & 54.2 & 14 & 30.4 & 27 & 27 & \\
\hline Positive & 11 & 45.8 & 32 & 69.6 & 43 & 43 & \\
\hline Do you wash your hands after each clinical appointment? & & & & & & & 0.036 \\
\hline Always & 58 & 74.4 & 121 & 85.8 & 179 & 81.7 & \\
\hline Sometimes & 20 & 25.6 & 20 & 14.2 & 40 & 18.3 & \\
\hline Use of personal protective equipment & & & & & & & 0.681 \\
\hline Always & 69 & 88.5 & 122 & 86.5 & 191 & 87.2 & \\
\hline Sometimes & 9 & 11.5 & 19 & 13.5 & 28 & 12.8 & \\
\hline Adherence to the biosafety protocol & & & & & & & 0.627 \\
\hline Always & 68 & 87.2 & 126 & 89.4 & 194 & 88.6 & \\
\hline Sometimes & 10 & 12.8 & 15 & 10.6 & 25 & 11.4 & \\
\hline Have you ever had an accident with sharp instruments? & & & & & & & 0.725 \\
\hline No & 39 & 50.0 & 74 & 52.5 & 113 & 51.6 & \\
\hline Yes & 39 & 50.0 & 67 & 47.5 & 106 & 48.4 & \\
\hline If yes, how many times? & & & & & & & $0.599^{* *}$ \\
\hline Once & 18 & 46.2 & 22 & 32.8 & 40 & 37.7 & \\
\hline Twice & 13 & 33.3 & 27 & 40.3 & 40 & 37.7 & \\
\hline Three times & 5 & 12.8 & 11 & 16.4 & 16 & 15.1 & \\
\hline Four times & 3 & 7.7 & 7 & 10.4 & 10 & 9.4 & \\
\hline If yes, which instruments? & & & & & & & 0.748 \\
\hline Needle (recapping) & 25 & 64.1 & 45 & 67.2 & 70 & 66.0 & \\
\hline Other & 14 & 35.9 & 22 & 32.8 & 36 & 34.0 & \\
\hline If yes, did you follow the protocol? & & & & & & & 0.171 \\
\hline No & 15 & 38.5 & 35 & 52.2 & 50 & 47.2 & \\
\hline Yes & 24 & 61.5 & 32 & 47.8 & 56 & 52.8 & \\
\hline Total & 78 & 100.0 & 141 & 100.0 & & & - \\
\hline
\end{tabular}

*Fisher's exact test; **Maximum likelihood ratio 
Table 4 - Gross and adjusted multivariate analysis of the associations between the dependent variable and factors related to social and educational aspects, knowledge and professional practices, Sao Paulo, Brazil, 2019.

\begin{tabular}{|c|c|c|c|c|}
\hline \multirow{2}{*}{ Variables } & \multicolumn{4}{|c|}{ Logistic regression } \\
\hline & $\mathrm{OR}_{\text {crude }}(95 \% \mathrm{Cl})$ & $\mathrm{p}$-value & $\mathrm{OR}_{\text {Adiusted }}(95 \% \mathrm{Cl})$ & $p$-value \\
\hline Years in the public healthcare service & $1.033(1.001-1.065)$ & 0.044 & $1.041(1.001-1.081)$ & 0.043 \\
\hline \multicolumn{5}{|l|}{ Sex } \\
\hline Male & $1.729(0.971-3.076)$ & 0.063 & $1.580(0.782-3.193)$ & 0.202 \\
\hline Female & - & - & - & - \\
\hline \multicolumn{5}{|l|}{ Use of alcoholic beverages } \\
\hline No & - & - & - & - \\
\hline Yes & $2.029(1.149-3.584)$ & 0.015 & $1.741(0.875-3.466)$ & 0.114 \\
\hline \multicolumn{5}{|l|}{ Received guidance on hepatitis $B$} \\
\hline No & $6.000(1.574-22.873)$ & 0.009 & $6.935(1.398-34.408)$ & 0.018 \\
\hline Yes & - & - & - & - \\
\hline \multicolumn{5}{|l|}{ Knowledge on the etiologic agent } \\
\hline Incorrect answer & $2.828(1.585-5.043)$ & 0.000 & $2.609(1.303-5.226)$ & 0.007 \\
\hline Correct answer & - & - & - & - \\
\hline \multicolumn{5}{|l|}{$\begin{array}{l}\text { How many doses of the vaccine against } \\
\text { hepatitis B did you receive? }\end{array}$} \\
\hline Do not know/Do not remember & $5.810(2.196-15.366)$ & 0.000 & $3.437(1.147-10.300)$ & 0.028 \\
\hline Less than three doses & $6.100(2.658-13.999)$ & 0.000 & $8.760(3.502-21.913)$ & 0.000 \\
\hline Three doses or more & - & - & - & - \\
\hline \multicolumn{5}{|c|}{$\begin{array}{l}\text { Do you wash your hands after each clinical } \\
\text { appointment? }\end{array}$} \\
\hline Always & - & - & - & - \\
\hline Sometimes & $2.086(1.042-4.177)$ & 0.038 & $1.292(0.558-2.993)$ & 0.550 \\
\hline
\end{tabular}

of years of practice is a risk factor, as each additional year increased the risk of non-immunization was $\mathrm{OR}=1.041$; 95\% CI 1.00-1.08. Likewise, participants who did not receive any guidance on hepatitis $\mathrm{B}$ and those who confused the etiologic agent had OR=6.935; 95\% CI 1.39-34.40 and $\mathrm{OR}=2.609 ; 95 \%$ CI 1.30-5.22. i.e. had more chances not to be immunized, respectively. Participants who did not know/did not remember how many vaccine doses they had received showed OR=3.437; 95\% CI 1.14-10.30, having more chances not to be immunized, while those who had received less than three doses had $\mathrm{OR}=8.760$; 95\% CI 3.50-21.91 of non-immunization compared to those who had three or more doses (Table 4).

\section{DISCUSSION}

This is one of the first studies carried out with dental surgeons in the PHS, in Brazil, aiming at mapping the immunization of these professionals using the immunochromatographic technology to identify the level of anti-AgHBs antibodies in this specific population.

This investigation found that $35.6 \%$ of dental surgeons in the PHC were not immunized against HBV, pointing out a contrast between professional vulnerability and self-care negligence.

In Brazil, after more than 30 years since the vaccine against hepatitis B was introduced in the national immunization program in the PHS, the adhesion of dental academics and dental surgeons is still inconsistent and negligent, as shown by the anti-HBs seroconversion assay ${ }^{17}$. Although health institutions recommend and guide immunization, some professionals do not follow the regulations, causing a failure in their self-care. In addition, the lack of efficient mechanisms for inspection and control of these health actions contributes to this negligent and reckless behavior.

By analyzing studies performed with dental professionals in other countries, we observed a different situation in comparison with the one identified in this study. In Iran, $11.5 \%$ of professionals were not immunized against HBV; in Spain, the estimate was $27.02 \%^{21}$; in Italy, $17 \%^{22}$; in the Netherlands, $12 \%^{23}$; and in the USA, only $7.1 \%^{24}$. What may justify this high prevalence of non-vaccination or non-protection among Brazilian dental surgeons is the possibility of a gradual decline of antibody levels, from 13 to $60 \%$, one year after the end of the immunization schedule ${ }^{21}$. 
Other factors associated to anti-HBs seroconversion can affect the production of antibodies, reducing the effectiveness of vaccinated individuals' immunization, such as vaccine storage methods, correct administration of doses, the immunization program and the protocol followed by each healthcare service ${ }^{25}$. In addition, we verified through a systematic review and meta-analysis that male, adult, elderly individuals with BMI (Body Mass Index) $\geq 25$, who smoke and have concomitant comorbidities, have higher risks of immunization failure, reinforcing the importance of performing the anti-HBs evaluation, and providing booster doses of the vaccine against $\mathrm{HBV}^{26}$

Another expressively relevant issue in this study was the association between the number of vaccine doses and the non-immunization of dental surgeons. This association was due to the non-completion of the immunization schedule by the study participants (they did not remember or they received less than three doses), justifying the deficient immune protection ${ }^{20,27}$.

Nowadays, thanks to the evolution of genetic engineering, the immunization schedule comprises three doses, which must respect the administration interval between them $(0$ 30,180 days), so that the immunization against the virus is guaranteed, with anti-HBs titers higher than $10 \mathrm{mIU} / \mathrm{mL}^{2}$. Concerning the vaccine coverage, a study conducted with participants in Australia, Belgium, Canada, Czech Republic, Germany, New Zealand, the Philippines, Russia, Spain, and the United States determined that the protective response occurs in $95 \%$ of children and adolescents, $90 \%$ of health young adults up to 49 years old, and $\geq 80 \%$ of individuals aged 60 years old or over ${ }^{28}$. In addition, according to WHO, immunosuppressed and hemodialised individuals have $50-70 \%$ of immunization against $\mathrm{HBV}$, and individuals with liver disease have $60-70 \%{ }^{29}$.

However, the knowledge and confirmation on the immunization status through the anti-HBs test is not recommended to the whole population because of the vaccine effectiveness. Nevertheless, health professionals, due to their vulnerability and exposure to occupational unhealthy procedures, are supposed to confirm their protection and be concerned with the maintenance of this status $^{20,30,31}$. For the same reason, individuals with low antibody levels and complete immunization schedule need to receive a booster dose, because, despite the premise of immunological memory, this supplementary dose is recommended to this vulnerable group, given their exposure to the main modes Hepatitis B transmission².

Regarding the knowledge of dental surgeons about the subject approached, we found gaps concerning elementary issues of hepatitis B, modes of transmission, and disease prevention in the dental clinic context. The statistical analysis pointed out the influence of this dimension on the representativeness of non-immunized individuals.

This association confirms the relevance of professional training, since acquiring this knowledge reflects in the practices and self-care conducts of dental professionals. Costa $e t ~ a l .{ }^{32}$ observed that primary health care workers who have more knowledge on occupational health are more favorable to vaccination. Other studies observed this same behavior in Brazilian and Lithuanian dental surgeons, especially in the younger ones ${ }^{33,34}$. Garbin et al. ${ }^{35}$ analyzed the knowledge of PHC dental surgeons and concluded that the representativeness of hepatitis B in the professionals' concept does not match its actual pathogenic and epidemiological significance, requiring more professional preparation measures to face diseases in public health and disrupt critical nodes.

Regarding professional practices, even without the confirmation of statistically significant associations, we found a high percentage of participants with a recurrent history of accidents with sharp equipments, mainly when recapping needles. Other studies have also observed this occurrence $^{11,32}$, and they suggested the need for a continuous training of dental professionals and thematic debates in the workplace to provide dental surgeons with knowledge and showing them the value of self-care measures.

A decrease in diseases caused by work activities in healthcare settings happened after recognizing the biosafety axiom in the medical practice, the use of personal protective equipment, and the creation of protocols on pre- and postexposure to contaminated materials and fluids ${ }^{36}$. However, even with minimized occupational risks, accidents are still significantly frequent. Their potential of developing diseases in non-immunized individuals must be considered, particularly regarding $\mathrm{HBV}$, since its infectivity ranges from 6 to $30 \%$ in accidents with sharp materials and blood known to be contaminated. A tiny amount of contaminated blood $(0.0001 \mathrm{~mL})$ is enough to transmit the pathogen ${ }^{37}$.

The laboratory method used in this study was the immunochromatographic technology-based rapid assay due to its suitability for the investigation and screening at the population level, in endemic areas or in vulnerable groups. This method's advantages are the low cost, high specificity, rapid test processing, easy technical features, diagnosis efficiency, high patient's acceptance, and no need for a laboratory infrastructure ${ }^{38-40}$. Further, we chose this technology based on the WHO's guidelines to track the HBV antigen and antibody levels and to eliminate hepatitis $\mathrm{B}$ as one of the main threats to public health ${ }^{3}$.

Due to the cross-sectional, epidemiological nature of this study, its limitations included the use of a questionnaire assessing memory-based variables, so the answers given 
in the questionnaire application have a potential for bias. The study results indicated the presence of individuals immunized against HBV who stated they were not vaccinated $(n=3)$ and had less than three doses of the vaccine $(n=10)$. This contradiction can be explained by the fact that these participants did not show their immunization record during data collection and, due to the memorybased variables, these data can be biased. In addition, we used the rapid immunochromatographic assay to analyze the immunization of participants against HBV, which has a lower specificity and sensitivity rate when compared to other laboratory methods. However, this technique has several advantages and is used in population studies.

\section{CONCLUSION}

We found a considerable number of dental surgeons in the Public Health System non-immunized against HBV. They are vulnerable and exposed to the main modes of virus transmission, especially due to the high prevalence of occupational accidents. Furthermore, knowledge, years in the public service and the value given to self-care related to the immunization schedule completion affected the vaccine protection.

\section{ACKNOWLEDGMENTS}

This study was financed in part by the Coordenação de Aperfeiçoamento de Pessoal de Nivel Superior - Brazil (CAPES) - Finance Code 001.

\section{AUTHORS' CONTRIBUTIONS}

CAS Garbin and TA Saliba designed the study, the data collection tool and wrote the article; B Wakayama and OA Saliba Junior carried out the data collection, the analysis and interpretation of data and wrote the article; AJI Garbin designed the study and critically reviewed the article.

\section{REFERENCES}

1. World Health Organization. Guidelines for the prevention, care and treatment of persons with chronic hepatitis B infection. Geneva: WHO; 2015. [cited 2019 Nov 15]. Available from: https://www.who.int/hiv/pub/hepatitis/hepatitis-b-guidelines/ en/

2. World Health Organization. Global hepatitis report, 2017. Geneva: WHO; 2017. [cited 2019 Nov 15]. Available from: https://www. who.int/hepatitis/publications/global-hepatitis-report2017/en/

3. World Health Organization. Guidelines on hepatitis B and C testing. Geneva: WHO; 2017. [cited 2019 Nov 15]. Available from: https://www.who.int/hepatitis/publications/guidelineshepatitis-c-b-testing/en/

4. Tauil MC, Amorim TR, Pereira GF, Araújo WN. Mortalidade por hepatite viral B no Brasil, 2000-2009. Cad Saude Publica. 2012;28:472-8

5. Weinbaum C, Lyerla R, Margolis HS. Prevention and control of infections with hepatitis virus in correctional settings. MMWR Recomm Rep. 2003;52:1-36.

6. Bensalem A, Selmani K, Narjes H, Bencherifa N, Soltani M, Mostefaoui F, et al. Widespread geographical disparities in chronic hepatitis B virus infection in Algeria. Arch Virol. 2017;162:1641-8.

7. Hadziyannis SJ. Natural history of chronic hepatitis B in EuroMediterranean and African countries. J Hepatol. 2011;55:18391.

8. Adenlewo OJ, Odeosun PO, Fatusi OA. Medical and dental students' attitude and practice of prevention strategies against hepatitis B virus infection in a Nigerian university. Pan Afr Med J. 2017;28:33

9. Ziglam H, El-Hattab M, Shingheer N, Zorgani A, Elahmer O. Hepatitis B vaccination status among healthcare workers in a tertiary care hospital in Tripoli, Libya. J Infect Public Health. 2013;6:246-51.

10. Karaivazoglou K, Triantos C, Lagadinou M, Bikas C, Michailidou M, Kalafateli M, et al. Acceptance of hepatitis B vaccination among health care workers in Western Greece. Arch Environ Occup Health. 2014;69:107-11.

11. Martins RJ, Moimaz SA, Sundefeld ML, Garbin AJ, Gonçaves PR, Garbin CA. Adherence to standard precautions from the standpoint of the Health Belief Model: the practice of recapping needles. Cien Saude Coletiva. 2015;20:193-8.

12. Moodley R, Naidoo S, Wyk JV. The prevalence of occupational health-related problems in dentistry: a review of the literature. J Occup Health. 2018;60:111-25.

13. Ramich T, Eickholz P, Wicker S. Work-related infections in dentistry: risk perception and preventive measures. Clin Oral Investig. 2017;21:2473-9.

14. Almutairi R, Almutairi M, Alsugair A, Alseraikh M, Almutairi H. Senior health sciences students' perception of occupational risk of viral hepatitis and attitudes toward patients diagnosed with viral hepatitis B and C. Int J Health Sci (Qassim). 2017;11:28-34.

15. Nelson NP, Easterbrook PJ, McMahon BJ. Epidemiology of hepatitis B virus infection and impact of vaccination on disease. Clin Liver Dis. 2016;20:607-28.

16. World Health Organization. Hepatitis B vaccines: WHO position paper - July 2017. Wkly Epidemiol Rec. 2017;92:369-92.

17. Wakayama B, Garbin CA, Garbin AJ, Saliba TA, Garbin AJ. Hepatitis B immunization analysis: tracking of antibody levels among dental patients. J Contemp Dent Pract. 2019;20:13-9.

18. São Paulo (Estado). Secretaria da Saúde. Decreto No 51.433 , de 28 de dezembro de 2006. Cria unidade na Coordenadoria de 
Regiões de Saúde, da Secretaria da Saúde, altera a denominação e dispõe sobre a reorganização das Direções Regionais de Saúde. Diário Oficial do Estado de São Paulo, São Paulo, 29 dez. 2006. Seção 1:1. [cited 2019 Nov 15]. Available from: https://www.al.sp.gov.br/repositorio/legislacao/decreto/2006/ decreto-51433-28.12.2006.html

19. Brasil. Ministério da Saúde. Gabinete do Ministro Portaria N³99, de 22 de fevereiro de 2006. Divulga o pacto pela saúde 2006 - consolidação do SUS e aprova as diretrizes operacionais do referido pacto Diário Oficial da União, Brasília, 22 fev. 2006. [cited 2019 Nov 15]. Available from: http://bvsms.saude.gov. br/bvs/saudelegis/gm/2006/prt0399_22_02_2006.html

20. Momeni N, Ahmad Akhoundi MS, Alavian SM, Shamshiri AR, Norouzi M, Mahboobi N, et al. HBV vaccination status and response to hepatitis B vaccine among Iranian dentists, correlation with risk factors and preventive measures. Hepat Mon. 2014;15:e20014.

21. Arias-Molis MT, Rojas L, Liébana-Cabanillas F, Bernal C, Castillo F, Rodríguez-Archilla A, et al. Serologic control against hepatitis B virus among dental students of the University of Granada, Spain. Med Oral Patol Oral Cir Bucal. 2015;20:e56671.

22. Petti S, Messano GA, Scully C. Antibody level and immunity against hepatitis B virus infection among general dental prectitioners. Acta Stomatol Naissi. 2013;29:1273-8.

23. van Wijk PT, Meiberg AE, Bruers JJ, Groenewold MH, van Raalten AL, Dam BA, et al. The risk of blood exposure incidents in dental practices in the Netherlands. Community Dent Oral Epidemiol. 2012;40:567-73.

24. Spradling PR, Williams RE, Xing J, Soyemi K, Towers J. Serologic testing for protection against hepatitis B virus infection among students at a health sciences university in the United States. Infect Control Hosp Epidemiol. 2012;33:732-6.

25. Wu Z, Bao H, Yao J, Chen Y, Lu S, Li J, et al. Suitable hepatitis B vaccine for adult immunization in China: a systematic review and meta-analysis. Hum Vaccin Immunother. 2019;15:220-7.

26. Yang S, Tian G, Cui Y, Ding C, Deng M, Yu C, et al. Factors influencing immunologic response to hepatitis B vaccine in adults. Sci Rep. 2016;6:27251.

27. Borch A, Kolster C, Gluud C, Gluud LL. Vaccines for preveting hepatitis B in healthcare workers (an updated protocol). Cochrane Database Syst Rev. 2017;2017:CD012695.

28. Van Der Meeren O, Crasta P, Cheuvart B, De Ridder M. Characterization of an age-response relationship to GSK's recombinant hepatitis B vaccine in healthy adults: an integrated analysis. Hum Vaccin Immunother. 2015;11:1726-9.

29. Petry A, Kupek EJ. Efetividade das vacinas anti-VHB (DNArecombinante) em doadores de sangue de uma região endêmica para hepatite B no sul do Brasil. Rev Soc Bras Med Trop. 2006;39:462-6.
30. Souza FO, Freitas PS, Araújo TM, Gomes MR. Vacinação contra hepatite B e Anti-HBS entre trabalhadores da saúde. Cad Saude Coletiva. 2015;23:172-9.

31. Jouneghani AS, Chaleshtori MH, Khoshdel A, Kheiri S, Farrokhi E, Khalafian P, et al. Evaluation of response to hepatitis B vaccine in Iranian 6-18-year-old students. J Res Med Sci. 2017;22:116.

32. Costa FM, Martins AM, Lima CA, Rodrigues QF, Santos KK, Ferreira RC. Fatores associados à verificação da imunização pós-vacinação contra hepatite B entre trabalhadores da Atenção Primária. Cad Saude Coletiva. 2017;25:192-200.

33. Costa FM, Martins AM, Santos Neto PE, Veloso DN, Magalhães VS, Ferreira RC. Is vaccination against hepatitis B a reality among Primary Health Care workers? Rev Lat Am Enfermagem. 2013;21:316-24.

34. Rimkuviene J, Puriene A, Peciuliene V, Zaleckas L. Percutaneous injuries and hepatitis B vaccination among Lithuanian dentists. Stomatologija. 2011;13:2-7.

35. Garbin CA, Wakayama B, Dias IA, Bertocello LM, Garbin AJ. Hepatite B e exposição ocupacional no cenário odontológico: a valoração do saber e das atitudes dos profissionais. J Health Sci. 2017;19:209-13.

36. Rostamzadeh M, Afkhamzadeh A, Afrooz S, Mohamadi K, Rasouli MA. Dentists' knowledge, attitudes and practices regarding Hepatitis B and C and HIV/AIDS in Sanandaj, Iran. BMC Oral Health. 2018;18:220.

37. Moreira CR, Saraceni CP, Oba IT, Spina AM, Pinho JR, Souza LT, et al. Soroprevalência da hepatite B e avaliação da resposta imunológica à vacinação contra a hepatite $\mathrm{B}$ por via intramuscular e intradérmica em profissionais de um laboratório de saúde pública. J Bras Patol Med Lab. 2007;43:313-8.

38. Ivantes CA, Silva D, Messias-Reason I. High prevalence of hepatitis $\mathrm{C}$ associated with familial history of hepatitis in a small town of south Brazil: efficiency of the rapid test for epidemiological survey. Braz J Infect Dis. 2010;14:483-8.

39. Cruz HM, Scalioni LP, Paula VS, Miguel JC, Ó KM, Milagres FA, et al. Poor sensitivity of rapid tests for the detection of antibodies to the hepatitis B virus: implications for field studies. Mem Inst Oswaldo Cruz. 2017;112:209-13.

40. Mboumba Bouassa RS, Nodjikouambaye ZA, Sadjoli D, Moussa AM, Adawaye C, Koyalta D, et al. Usefulness of simultaneous screening for HIV- and hepatitis C-specific antibodies and hepatitis B surface antigen by capillary-based multiplex immunochromatographic rapid test to strengthen prevention strategies and linkage to care in childbearing-aged women living in resource-limited settings. Open Forum Infect Dis. 2018;5:ofy069. 